\title{
The Necessity and Teaching Mode of Turning Classroom Teaching Under M-learning Mode in Colleges and Universities
}

\author{
$\operatorname{Nan} \operatorname{Lu}^{1, a^{*}}$ \\ ${ }^{1}$ Foreign Language Department, Qiqihar Medical University, Qiqihar 161006, China \\ a729963040@qq.com \\ * the corresponding author
}

Keyword: University; M-learning mode; Flipped classroom; Teaching model

\begin{abstract}
The key to improve the quality of higher education is to renew teaching ideas and improve teaching methods. Therefore, it is urgent to find a new way of teaching reform. With the widespread spread of the flipped classroom teaching mode, a new approach to solve the teaching quality has emerged. This study tries to analyze the application necessity of classroom teaching in college classroom by analyzing the concept of "flipped classroom" in M-learning mode, and constructs a "flipped" classroom teaching model suitable for college classroom teaching. This paper tries to find a new and effective way to change the present situation of classroom teaching in Colleges and universities so as to improve the effect of classroom teaching.
\end{abstract}

\section{Introduction}

In college classroom teaching, the traditional classroom teaching model still plays a leading role in teaching. Teachers are still on the platform, students sit on the platform to listen to, teachers are still classroom teaching "dictator."". The wide spread of the flipped classroom teaching model provides a new idea for the further development of higher education reform. The main feature of the flipped classroom teaching is to impart knowledge and to internalize the knowledge in class.

Before the course of knowledge transfer, students through the rich learning resources for independent learning, learning support, self-study guarantee. In the course of the teacher set up before the problem of cooperation, inquiry, interaction, discussion, to form a conclusion.Students in the classroom can also ask questions, and teachers answer questions, students encounter problems with teacher help, timely feedback, to achieve the purpose of knowledge internalization.

This is to give full play to students' individuality, autonomy, innovation, discovery and solution. The new teaching mode coincides with the requirement of improving the quality of higher education in the reform of higher education.

\section{M-learning Model and Flipped Classroom}

$\mathrm{M}$ - leaHling is the abbreviation of mobile leaming, which is usually translated into mobile learning in china. It refers to the remote learning of intelligent terminal equipment (such as mobile phones, PDA, etc.) under the guidance of lifelong learning. This is the new development stage of modern educational technology applied in teaching. M.leaming can realize free learning anytime, anywhere. With the development of mobile technology, the teaching mode has been transferred from e-learning to mobile learning ( $\mathrm{M}$ - leaming). In January 16, 2014, the China Internet Network Information Center (CNNIC) issued its thirty-third statistical report on the development of China's internet. The report shows that as of December 2013, China's Internet users reached 6.18Million, mobile phone users reached 500 million, continue to maintain steady growth. 10 to 29 years old accounted for 55.3\% of Internet users, students are still the largest group of China users, accounting for $25.5 \%$, mobile phone Internet users accounted for $81 \%$. As the mobile computing technology (Mobile Computing) the development of mobile intelligent terminal equipment has become an indispensable product in people's lives, with intelligent terminal equipment in the ratio of increase in college students, it is possible to implement M.1 eaming in universities. 
The flipped classroom is a new teaching mode which turns the traditional learning process over. Professor Roben Talbert of the Franklin Institute in the United States, after many years of flipped classroom teaching experiments, summed up the structural model of classroom implementation of public identification Fig. 1.The basic meaning is the application of teaching video and the reverse of the teaching process. But we don't think that flipping classes is just teaching videos to reverse classroom teaching. In fact, with the development of modern information technology and its wide application in the field of education, integration of technology and teaching more deeply, all aspects of the various elements in the process of learning, the classroom has changed, changed the subversive teaching mode, teaching idea, school education teaching is facing profound changes.

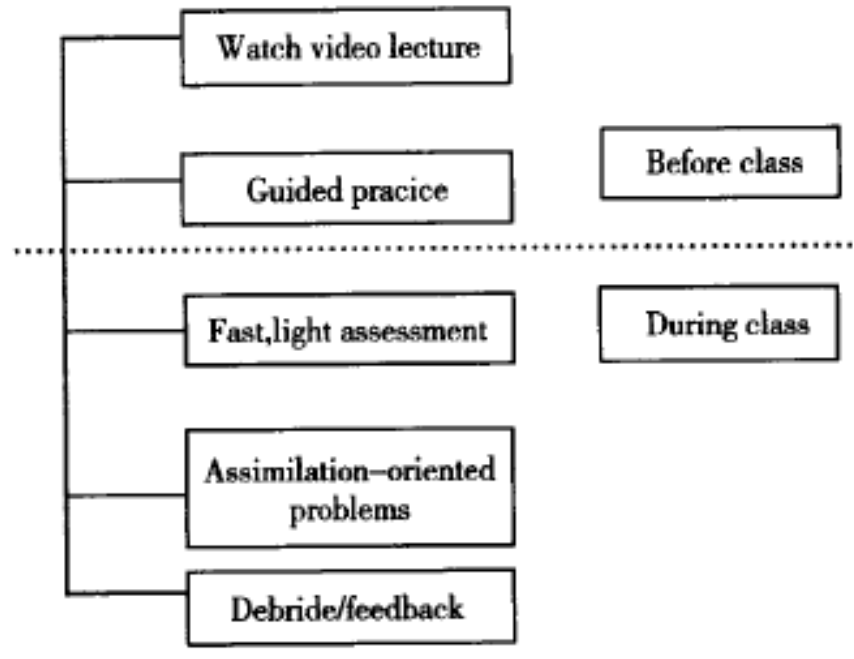

Figure 1. Roben Talbert Flipped classroom implementation diagram

\section{The Necessity of Turning Classroom Teaching Under the Mode of M-learning Implementation in Colleges and Universities}

Satisfying Individualized Learning and Respecting Individual Difference Development. One of the important factors that affect the quality of teaching in Colleges and universities is that it is difficult for students to adapt themselves to different abilities. The expansion of students, increase the number of students in the same class, school level is uneven, some are very interested in learning, some feel it difficult to keep up with the learning progress of the teaching content, and some even give up professional courses to sports activities.College teachers have such experience, it is difficult to control the students to class rate and quality of study.The "turn over class" meets the goal of emphasizing individual self-development in universities, and students can choose courses independently and control their learning progress freely according to their own knowledge absorptive capacity.Some students have too many tasks or other non - learning activities, so they can study at their own pace to help them make more rational use of their time. Some students can't adapt to the large amount of teaching content in the University, but they can play it freelyLearn video, courseware, adjust their learning progress. With the technical support, the flipped class can meet the different needs of students at different levels.Students can learn their own pace, choose their own time and place to study, and they can control their content and learning. The application of classroom theory in college teaching embodies the student centered approachRespect the individual difference development of students.

Lighten the Pressure of Teachers' Work and Improve the Quality of Teaching. In recent years, due to the expansion of college enrollment, the workload of teachers is also increasing, especially as the elective course teachers, door number, number of classes and homework are very large, the teaching quality has been greatly affected.The implementation of "flip classroom", the teaching of knowledge in video, courseware and other forms of network electronic documents to students, so that students can complete part of the study before the course. 
In the course, the teacher can reduce the knowledge point instruction, and increase the time for teacher and student to communicate and solve the problem.In the process of communication and solving problems, teachers have more time to understand the students' learning state, so as to better adjust the progress of the course teaching. This kind of teaching mode which reduces classroom instruction and increases classroom communication can reduce the teaching pressure of teachers, better grasp the progress of teaching, adjust the focus of teaching, and improve the quality of teaching.

\section{Teaching Mode of Flipped Classroom Teaching under M-learning Mode in Colleges and Universities}

Curriculum Development. The main tasks of the course development are courseware database making, video library recording, question base production, case base making and other related materials making.

Courseware library, video library data, according to the cognitive rules of nature and student curriculum, targeted instructional design, the author thinks that the video to micro fine course form good.Micro courses video time is short, generally 10 minutes or so, control the concentration of students in the time range of concentration.Each of the micro video is based on the teaching design recorded, the content is generally knowledge of the curriculum. Resource library material, first of all the course of each chapter of the knowledge points and teaching requirements for analysis. Then write the teaching design, including syllabus compilation, courseware design, teaching design, case study and other video exercises.Finally, according to the design results, courseware, video recording and case library data are produced and input into the mobile learning platform. The production of the curriculum resource base is the foundation of the mobile learning platform and plays a key role in the implementation of the following flipped classroom.

Imparting Knowledge Before Class. The most important feature of flipped class is the students' autonomous learning before class, and the activity before class becomes an important part of turning class.Before class, the teaching of knowledge mainly consists of two aspects. On the one hand, the teacher makes definite study tasks; on the other hand, students study before class according to the tasks formulated.In the process of developing mobile learning platform, the knowledge transfer module is a difficult point and a key link in the implementation of the classroom. The design of this link is mainly focused on the design of learning tasks and the control of learning progress, And meet the individual learning needs of learners.In the module of pre knowledge instruction, the students' role mainly consists of two parts: accepting the task of learning and looking at the historical task.Teacher's role is mainly to develop, push various learning tasks, as well as personalized guidance to students.

The Sublimation of Knowledge in Class. Through the pre class knowledge transfer, students' learning tasks, "customs clearance" process has mastered the basic knowledge, teachers in the classroom with the progress of the students to organize classroom activities.In the course of teaching, many unnecessary knowledge and teaching time are reduced. Teachers can fully arouse the enthusiasm of students, encourage students to explore independently, create situational dialogues, and solve the remaining problems.

By completing the task of studying before class, we should carry out individual tutorship in the course, realize difference teaching, and improve the whole teaching quality.

After Class Evaluation Summary. Through classroom teaching activities, students summarize and feedback their own learning results, and put forward suggestions for improvement.Teachers collect and feedback the effects or opinions of the feedback, record the deficiencies in the teaching process, and adjust and formulate the next learning task.

\section{Concluding remarks}

The paper introduces the advantages of the mobile terminal and the flipped classroom, puts forward the implementation of mobile learning in Colleges and universities (M-learning) the necessity of flipping the classroom teaching mode, for the design of modern college students' learning teaching mode.The development of mobile computing technology, accelerate the development of M-learning platform, the new mobile technology combined with the flipped classroom concept applied to teaching, students can not only 
meet the individual learning needs, and can let the teachers have been liberated from the classroom, from the leader of teaching to study auxiliary.

\section{Acknowledgments}

This work was financially supported by Qiqihar Medical University Teaching-Research Project: The Application of M-learning in College English Teaching in LAN Environment, Project Number: QYJY20160031

\section{References}

[1] Jeremy F.Strayer. How learning in an inverted classroom influences cooperation, innovation and task orientation[J].Learning Environ Res, 2012(15):171-193.

[2] Baker,J.w.The"classroom flip":Using web course management tools to become the guide be side[A].Paper presented at the 11 th Intemational Conference On the College Teaching and leaching,2000,4:50-5 1.

[3] Fulton,Kathleen.The Flipped Classroom:Transforming Education at Byron Higll [J].Tustin:T.H.E.Journal,201,6:1 8-20.

[4] Berrett,Dan.How Flipping the Classroom Can Improve the Traditional Lecture[J].Ann Arbor:The Education Digest.2012,5:36-41.

[5] Maureen J.Lage,Glenn J.Platt,Michael Treglia. Inverting the class- roonll A gateway t0 creating an inclusive learning environment[J]. The Journal of Economic Education,2000,(1):30-43. 